\title{
Vt cecinit poeta: The presence of Virgil in Rodrigo de Castro's De uniuersa mulierum medicina
}

\author{
Gabriel A. F. Silva \\ (University of Lisbon)
}

\begin{abstract}
De uniuersa mulierum medicina, by the Portuguese physician Rodrigo de Castro, is a complex gynaecological treatise that comprises sources concerning various medical aspects, both ancient and contemporary to the author, and also non-technical sources, namely poets from classical antiquity. This being the first article on the presence of Virgil in Castro, the main goal is to see where Virgil's Georgics 4 and Aeneid 6 are used in the De uniuersa mulierum medicina and explore how passages from the Virgilian oeuvre were used by the Portuguese physician.
\end{abstract}

\section{Keywords}

Rodrigo de Castro; Virgil; Georgics; Aeneid; medicine 


\section{Introduction ${ }^{1}$}

Rodrigo de Castro (c. 1550 Lisbon-c. 1627 Hamburg) was a Portuguese physician of Jewish origin. He belonged to a family of renowned doctors, some of whom had served the Portuguese monarchy. It is probable that he studied in Salamanca and Évora and, after obtaining his doctorate, exercised medicine in Lisbon. Perhaps to escape from the Inquisition, he went to Hamburg, where he published his major work, De uniuersa mulierum medicina. ${ }^{2}$

This monumental treatise comprises two parts: part one concerns theory (De natura mulierum), part two has a practical nature (De morbis mulierum). Castro shows knowledge of the medical tradition that preceded him, from Antiquity (including, for example, Hippocrates and Galen) to his own time (with Amato Lusitano and Luis Mercado, among many others). ${ }^{3}$ Castro was also well aware of the importance of his magnum opus, as he states in the preface to the first edition that other books about gynaecology had been published but describes them as incomplete or confusing, and failing to deal with the subject properly. ${ }^{4}$

It is not surprising that Castro had a deep knowledge of the Hippocratic and Galenic doctrines, among many other ancient and contemporary medical authors. What may seem curious is the use he makes of ancient poets whose works have nothing to do with medicine, Virgil for instance. This leads us to the first question of this article: how familiar was Rodrigo de Castro with the works of Virgil? It must be noted that knowledge of authors from Graeco-Roman antiquity in Castro's time was acquired in grammar lessons, and pupils had contact with the major authors of Latin literature at school. ${ }^{5}$ In

1 This article was supported with national funding by the Portuguese Foundation for Science and Technology (FCT) within the framework of the project 'Gynecia: Rodericus a Castro Lusitanus and the ancient medical tradition about gynaecology and embryology' (Ref. PTDC/FER-HFC/31187/2017). I am grateful to Cristina Santos Pinheiro, Gregorio Rodríguez Herrera, Maria Luísa Resende, and the anonymous reviewers for their comments and suggestions, which undoubtedly enriched this article.

2 De uniuersa mulierum medicina. Nouo et antehac a nemine tentato ordine absolutissimum opus; studiosis omnibus et utile, uero medicis pernecessarium (1603). In 1617 this work had a second edition, under a slightly different title (De uniuersa muliebrium morborum medicina...) and with corrections by the author. Castro is also the author of a shorter treatise about the plague that struck the city of Hamburg, Tractatus breuis de natura et causis pestis, published in Hamburg in 1596, and the Medicus-politicus (1614), a treatise concerning many subjects, among which the value of medicine and the physician's training. For further information on Rodrigo de Castro's life and work, see Kayserling (1901-1906), s.v. 'Rodrigo de Castro'; Arrizabalaga (2009: pp. 109-114); Förg (2020: pp. 47-82); and Mota \& Pinheiro \& Silva (forthcoming).

3 Cf. Pinheiro (2017: p. 292) on the structure of the treatise and for the sources used by Rodrigo de Castro.

4 Non tamen existimes, amice lector, nos actum agere, quia plures extent de mulierum morbis tractationes (...) Neque uero me latet, non ita pridem Basileae in aliquot uoluminibus congestos omnes fere auctores, qui de hoc negotio scripserunt, fuisse excusos: in quibus tamen supra enumerata incommoda procul dubio deprehendes ('However, do not think, dear reader, that what we are doing what has already been done, because it already exists many other treatises about women's diseases (...) I know that not long ago almost all the authors who wrote on this theme were printed in Basel, reunited in a few volumes: however, there you find, without doubt, all the defects listed above [i.e. being incomplete, confusing, failing to treat the subject appropriately]'). Castro is here referring to the Gynaeciorum libri, published in Basel in three editions (1566, 1586-1588, 1597). When not indicated, translations are mine.

5 Cf. Toipa (2017: pp. 353-373). See also Domingues (2002). 
the Medicus-politicus, more specifically the chapter 'Quinam auctores sint euoluendi et qualis debeat esse medici bibliotheca', Castro asserts that, besides authors writing on medical themes, a physician must also know the major authors of Greek and Latin literature (those writing on agriculture or historiographers, and the major poets) ${ }^{6}$ They are considered models, since the most prominent ancient authors used them as sources of inspiration for their own texts:

sunt insuper alii autores, ad quos diuertere interdum liceat, non uti ciui, sed ueluti peregrino: ex poetis quidem Homerus, Virgilius, Lucretius, horum enim testimonia clarissimi ac uetustissimi scriptores citare etiam consuerunt.

There are also other authors whom one is allowed to frequent from time to time, not in the same way as a fellow citizen, but like a stranger: certainly from among the poets, there are Homer, Virgil, Lucretius, whose testimonies the most famous and most ancient writers were accustomed to citing.

\section{Virgil and God: Adaptations of Ancient Themes}

The first chapter of De uniuersa mulierum medicina that contains verses from Virgil is 'De facultate formatrice' (1.2.8). Castro states, regarding the characteristics of the formatrix facultas, that this faculty is the potency of the anima uegetans, which, because of divine intervention, has wisdom. He says that this faculty was called thus because it does not operate freely, but rather depends on God's intervention. ${ }^{7}$ In this complex and philosophical chapter, Castro quotes four verses of Virgil:

\section{Deum namque ire per omnes}

Terras tractusque maris, caelumque profundum

Inde hominum pecudumque genus, uitae uolantum,

Et quae marmoreo fert, monstra sub aequore pontus.

For God they saw, pervades all things, earth and sea's expanse and heaven's depth, thence spring the races of men and beast, the life of winged creatures, and the monsters that ocean bears beneath his marble surface. ${ }^{8}$

In a marginal note, these verses are identified as belonging to Aeneid 6. However, the first two verses are clearly Georg. 4.221-222, concerning the divine origin of bees and of other kinds of living creatures, though the following couplet does indeed come from

6 For a complete description of Rodrigo de Castro's ideal library, see Cardoso (2012: pp. 159-167); and Frade \& Silva (2011: pp. 51-94).

7 It is interesting to note that the sentences preceding these quotations of Virgil are virtually identical to those of Rodrigues de Veiga's commentary on Galen's De locis affectis (1586: p. 416). This might show not only Castro's knowledge of the theme in question, but also medical authors' knowledge of each other, using and rearranging their colleagues' material for the purposes of their own works.

8 All translations of Virgil are from Fairclough (1999). 
Aeneid 6 (728-729). The passage from Georgic 4 touches on the notion that bees possess a divine intelligence. Mynors writes, commenting on the Georgics, that 'such a theory comes easily to those who accept the pantheistic ideas that there is god in all nature, and that the vital spirit in men and quadrupeds derives from a circumambient fiery aether, to which the bees (it seems) must have access too'. ${ }^{9}$ The couplet from Aeneid 6 features a moment of the katabasis that concerns the transmigration of the soul and the spirit that nourishes the sky and the earth. This spirit was, according to Horsfall, 'easily recognizable to the scantily-educated reader as the anima mundi, ${ }^{10}$ which, as Castro notes, was God, who rules all things in nature.

To an inexperienced eye, this connection of two excerpts from two different works might seem natural. The technique used by Castro, probably consciously, seems to be similar to the composition of a cento. ${ }^{11}$ If we regard the two excerpts, it is easy to see that they share content, vocabulary and structure, as if they belonged to the same poem:

deum namque ire per omnes

terrasque tractusque maris caelumque profundum.

Hinc pecudes, armenta, uiros, genus omne ferarum (Georg. 4.221-223)

inde hominum pecudumque genus uitaeque uolantum

et quae marmoreo fert monstra sub aequore pontus (Aen. 6.728-729)

Regarding the structure of Georg. 4.223, which is not quoted by Castro, one can see that it starts with the connector hinc, as Aen. 6.728 starts with inde, after which, the two lines comprise very similar elements that relate to a divine nature or spirit. Thus it does not seem unreasonable to think that Castro, having knowledge of both these pieces by Virgil, consciously linked them using the cento technique. With inde, now referring to deum of Georgic 4 as the origin of everything, Castro perfectly joins a handful of verses connected by both theme and style. It seems that Castro manipulated the text to serve the purpose of his chapter concerning divine influence on the elements. Thus, out of context, without further reference to the bees of the Georgics or the theory of the transmigration of the soul, Castro moulded the Virgilian text(s) in such a way that it would convey a message relevant to the content of his chapter, allowing him to harness Virgil's auctoritas.

We may be able to show that he manipulated both texts if we think about where he took these quotations from. Was Castro intimately acquainted with these lines or did he consult the Virgilian corpus somewhere, perhaps even specifically for the purpose iden-

9 Mynors (1990: p. 285). Trimalchio in Petronius' Satyricon states that bees are divine since they produce honey, the food of the gods. See Petron. 56: Apes enim ego diuinas bestias puto, quae mel uomunt, etiam si dicuntur illud a Ioue afferre. See Schmeling (2011: ad loc.).

10 Cf. Horsfall (2013: p. 488), who notes that 'the reader naturally thinks back to G. 4.219-227'.

11 This technique consists of taking verses from other authors, notably Homer and Virgil, to create a new poem in which they are given new meaning. For further information on this kind of poem, see, for example, Salanitro (1997: pp. 2314-2360) and McGill (2005). 
tified above? I do not mean to claim that he could not have had direct knowledge of Virgil, but I think one must bear in mind that there were other sources of information for ancient texts, namely the anthologies that circulated around Europe in his time, whose format and structure allowed a thematic search, not only by author, making available ancient authors to a wider range of people. ${ }^{12}$

The Illustrium poetarum flores of Octavianus Mirandula, one of the most well-known anthologies of Latin poetry, may be relevant to this investigation. ${ }^{13}$ Wilson-Okamura states that Mirandula's anthology is particularly useful because it tells us which passages of which ancient authors were most famous, and because its content is thematically organized. ${ }^{14}$ As can be seen in Figure 1 in the Appendix, Mirandula's chapter 'De Deo' presents, among others, three quotations of Virgil: Ecl. 3.60-61, Georg. 4.221-224 and Aen. 6.724-730. It seems possible to establish a parallel with the structure and order of Rodrigo de Castro's quotations from the same passages in his chapter 'De facultate formatrice'. Mirandula starts a subchapter concerning the anima mundi with a quotation from Ecl. 3.60, and Castro quotes part of the same line in his text:

idipsum est, quod uoluit Virgilius, dum Iouis omnia plena esse cecinit.

The quotation of these words, in this very specific context, seems to present a strong parallel with the content and structure of Mirandula's chapter about the presence of God in everything. If we consider that the third Eclogue is not generally the best known, and thus perhaps less likely to be quoted from memory than the first or the fourth, for example, it seems plausible to suggest that Rodrigo de Castro had recourse to this particular anthology. The passage from Georgic 4 may also offer some insight since Mirandula cut the first two words of the verse to make it fit the purpose of his chapter about God; Castro may have used this adaptation when quoting the same text. ${ }^{15}$

The next group of Virgilian verses follows a quotation of Avicenna focusing on the nature of the uirtus separatrix. Here the Portuguese physician states that everything in nature has been taught to obey the divine Creator. To illustrate this idea, Castro quotes Aen. 6.724-728:

12 Cf. Castro Jiménez (2006: p. 294).

13 Mirandula (1538). It is worth noting that there are many copies of Mirandula's anthology listed in the catalogues of the universities of Évora and Salamanca, where Rodrigo de Castro may have pursued his medical studies. This may indicate that the physician was familiar with and used this work. On Mirandula, see Moss (1996). The Illustrium poetarum flores, and other anthologies, may be consulted at the Excerpta Project website (http://excerpta.iatext.ulpgc.es).

14 Wilson-Okamura (2010: p. 184). On the use of the Aeneid in anthologies, see Curbelo Tavío \& Paso Carrasco (2020a: pp. 29-67). See also Curbelo Tavío \& Paso Carrasco (2020b: pp. 47-60) on the use of excerpts of the Appendix Vergiliana in anthologies.

15 It must also be noted that these Virgilian verses of the Georgics and the Aeneid are referenced, for example, by Augustinus Steucus in De perenni philosophia, in a context similar to this one in Rodrigo de Castro's treatise, concerning the anima mundi. Although Steucus uses these verses separately and correctly attributed, it shows that this topic was often employed in Castro's time, and that these verses, besides having a strong presence in anthologies, were associated with this specific theme. See Steucus (1540: pp. 86-87). 
Principio caelum, ac terras, camposque liquentes,

Lucentemque globum lunae, Titaniaque astra

Spiritus intus alit, totamque infusa per artus

Mens agitat molem et magno se corpore miscet,

Inde hominum pecudumque genus.

First know that heaven and earth and the watery plains, the moon's bright sphere and Titan's star, a spirit within sustains; in all the limbs mind moves the mass and mingles with the mighty frame. Thence spring the races of man and beast.

Once again, Castro uses the beginning of the exposition on the transmigration of the soul to show that everything, each of the faculties that govern the world, is animated by a divine spiritus, which is why animals follow their instinct:

Bruta animalia agnoscunt suos pastus, suas domos, suorum morborum remedia et herbas etiam nobis ignotas, caeterasque perficiunt functiones, uitulus cornu petit, priusquam cornua produxerit, pullus equinus nondum solidis unguibus calcitrat, catulus licet dentes nondum ualidos habeat, ad mordendum incitatur.

Irrational animals know their food, their habitats, the remedies for their diseases and even herbs that we ignore, and they perform other functions: the calf attacks with his horn before he has grown horns, the foal kicks with hoofs that are not yet solid, the puppy is driven to bite although his teeth are not yet strong.

The passage from the Aeneid is strongly influenced by Lucretius and his style, with its opening word principio, conveying a strong didactic purpose, as Horsfall asserts. ${ }^{16}$ The excerpt is connected to a later one from the Georgics, since at Georg. 4.221, the anima or spiritus that activates the universe is called deus. The identification of spiritus with the anima mundi would be clear to anyone. To conclude this idea, in his final Virgilian quotation in the chapter 'De facultate formatrice', after a quotation from Lucretius (3.741-742), Castro uses two and a half verses from Georg. 4.219-221, concerning the nature of bees:

\footnotetext{
His quidam signis atque haec exempla secuti

esse apibus partem diuinae mentis et haustus aethereos dixere...
}

Led by such tokens and such instances, some have taught that the bees have received a share of the divine intelligence, and a draught of heavenly ether...

These verses precede the first ones quoted above from the Georgics, and appear in Mirandula's anthology in a section called 'De animalibus'. Taking a look to the excerpt as a whole (Georg. 4.219-222), the second part is removed from its original context and appears in a different section, not concerning animals, but God.

16 See Horsfall (2013: p. 487). 
Further on, Castro discusses the possibility of reproduction between different species ('Possintne diuersa genere coire', 1.3.6) and offers a brief study of creatures like lemures, genii, laruae, pygmaei and gnomi, among others. Focusing more specifically on the differences between laruae and daemones, he talks about their essence and nature, highlighting their peculiarities and the tales associated with them. Here he quotes Aen. 6.730-734:

\author{
igneus est illis uigor et caelestis origo \\ seminibus, quantum non noxia corpora tardant \\ terrenique hebetant artus moribundaque membra. \\ hinc metuunt cupiuntque, dolent gaudentque, neque auras \\ respiciunt clausae tenebris et carcere caeco.
}

Fiery is the vigour and divine the source of those seeds of life, so far as harmful bodies clog them not, or earthly limbs and frames born but to die. Hence their fears and desires, their griefs and joys; nor do they discern the heavenly light, penned as they are in the gloom of their dark dungeon.

The Virgilian context of these lines is Anchises' explanation to Aeneas of the origin of the elements and the force that put them in motion. He states that it is a 'fiery vigour' that makes them move and that the origin of the elements is divine. This passage is thus adapted to its new context of a discussion concerning the nature of laruae and other creatures, making reference to their mortal condition and their non-human bodies, creating a connection to the previous context concerning the origin of elements.

\title{
2. From Proteus' Metamorphosis to Women's Suffocation
}

The last two quotations of Virgil in Castro's De uniuersa mulierum medicina are found in the second volume of the work, in the chapter 'De strangulatu ex utero' (2.2.1). In a scholium dedicated to this theme, Castro states that received wisdom has it that in cases of suffocation of the uterus, women sometimes make noises resembling animals:

Ab immundo spiritu corripi suffocatas uulgus existimat, quia solent plerumque in illis mirandae exaudiri uoces, ex imis uisceribus, nunc ueluti ranarum coaxatus, nunc serpentum sibili, crocitus coruorum, gallorum cucurritus, canum latratus...

People think that when they are suffocating they are possessed by a dreadful spirit, because they usually hear many astonishing voices coming from the depths of their entrails, now like the frog's croak, now the serpent's hiss, the crow's caw, the rooster's cluck and the dog's bark...

This idea that women may resemble animals may have been borrowed from Cornelius Gemma's De naturae diuinis characterismis, since Castro quotes very closely Gemma's words on this topic. ${ }^{17}$ In illustrating this popular belief, Castro uses Georg. 4.406-409:

17 Gemma (1575: p. 153): unde et uoces mirandas ex imis uisceribus exaudiri, nunc uelut ranarum coaxatus, nunc serpentum sibilos, crocitus coruorum, gallorum cucurritus, latratus canum... 
Tum uariae illudent species, atque ora ferarum,

Fient enim subito sus horridus, atraque tygris,

Squamosusque draco et fulua ceruice leaena

Aut acrem flammae sonitum dabit.

Then will manifold forms baffle you, and figures of wild beasts. For of a sudden he will become a bristly boar, a deadly tiger, a scaly serpent, or a lioness with tawny neck; or he will give forth the fierce roar of flame.

Castro warns his readers that one should not give up on the treatment, although it may seem difficult. To illustrate the persistence needed, the physician quotes Virgil, Georg. 4.411-414:

\section{Sed quanto ille magis formas se uertet in omnes,}

Tanto, nate, magis contende tenacia uincla:

Donec talis erit mutato corpore, qualem

Videris incepto tegeret cum lumina somno.

But the more he turns himself into all shapes, the more, my son, should you tighten his fetters, until after his last changes of body he becomes such as you saw when he closed his eyes at the beginning of slumber.

This episode comes from the famous epyllion of Aristaeus, where Cyrene gives her son clear instructions on how to learn the cause of the loss of his bees from the seer Proteus. Aristaeus will need strength to hold Proteus down for, as Cyrene warns him, he will assume the forms of a variety of animals in order to escape, and make their noises. Although this is a hard task, Aristaeus must be strong and to force Proteus to speak, regardless of the forms he may assume.

As above, these quotations may be seen as a show of erudition by Rodrigo de Castro. ${ }^{18}$ The popular belief that women suffering from uterine suffocation make noises resembling animals is connected to the variety of animal forms that Proteus assumes during his conflict with Aristaeus. If the treatment fails, Castro says that one must persist - the same advice that Cyrene gives Aristaeus. In contrast to his use of the other Virgilian quotations, here it seems that Castro is making use of personal knowledge of the Georgics and using it to bestow Virgilian auctoritas upon his own text.

This specific passage of the Georgics seems not to be well-represented among the anthologies of Castro's time, so his knowledge of the verses concerning Proteus' epyllion may come from his youthful studies. This being one of the best-known episodes of the Georgics - or even the most well-known - it should not be surprising that educated people knew it. The Ratio Studiorum recommends the fourth book of the Georgics as one of several texts with which to learn grammar: ${ }^{19}$

18 This might be what Conde Parrado (2001: p. 266) calls 'ornament quotes'.

19 Ratio atque Institutio Studiorum Societatis Iesu (1635: pp. 135-136). It is possible, as noted at the beginning of this article, that Castro had contact with Latin poets through his education before he began his medical training. Cf. also Miranda (2001: pp. 83-111) and Toipa (2017: pp. 358-360). 
altero quaedam item selecta, et purgata ex Catullo, Tibullo, Propertio, et Virgilii Eclogis; uel etiam libri eiusdem faciliores, ut quartus Georgicorum, quintus et septimus Aeneidos...

on the other hand, [there are] also a few selected and expurgated poems from Catullus, Tibullus, Propertius, and from Virgil's Eclogues, or more approachable books of Virgil, like the fourth of the Georgics, the fifth and the seventh of the Aeneid...

\section{Conclusion}

It is certain that Rodrigo de Castro knew the works of Virgil. But this knowledge, drawn from a scholastic basis common to all the educated people of his time, seems sometimes to come from secondary sources like anthologies, such as the Illustrium poetarum flores of Octavianus Mirandula. These anthologies repeatedly quote certain passages like the episode of Aeneid 6 concerning the transmigration of the soul, used by Castro. One can thus get an idea of what were the main texts used at that time. Nevertheless, literary knowledge was not only conveyed by anthologies: before starting his medical career, Castro, like all his educated contemporaries, had studied Latin grammar and literature, which would have brought him into contact with the poetry of Virgil, taught in schools since Antiquity. The limited number of texts and citations of Virgil may thus be related to both Castro's own school experience, to the common sourcebooks in vogue during his professional activity and to other medical sources known to Castro. By using Virgil's poetry, Rodrigo de Castro is not merely embellishing his gynaecological treatise, but also reinforcing the notion, as he would later note in the Medicus-politicus, that a great physician must have a vast culture and know a wide range of authors. 


\section{Appendix}

\section{Zi O R E}

94

Quigenies omnes, mariáq; $\sigma$ tcrras mourt,

Eius fum ciuis ciuitdte coelitum $\mathcal{\sigma} c$.

15. Manilius lib.r.Aftrono.

Deus est quinon mutatur in acho.

Nunquam tranfucr as folem decurrere ad arctos

Nec mutare uias, $v$ in ortumuertere curfus, Auroramó; nouis nafcentem oftendere tcrris,

Neclunam certos excedere luminis orbcs:

Sed feruare modum, quo cref cat, quóue recedat,

Nee cadercinterram pendentia/ydera coelo.

Deum mundianimam effe quidam afferunt

fed falfo.quia tunc paffibilis effet. nifi intel ligant quod Deus fit omniasi.oium caufa.

$$
\text { Vergilius Ecloga.3. }
$$

Ab Toue principium $\mathrm{Mu}$ a: louis omnia plena.

Ille colit terras, illi mea carrinina cure.

$$
\text { Idem lib.4.Georg. }
$$

Deumnanq; ire peromnes

Terras $\tilde{q}_{;}$, trattus $q_{;}$maris, coelumq; profundum

Hinc pecudes, armienta, uiros, genus omne feraruin

Quemq; fibitenues nafocntem arcefcere witas.

... Idem lib. . . Aeneia.

Principio coelum ac terras, camposq; liquentes,

Lucentemg; globumlune, Titamíá; aftra

Spiritus intus dlt, totainq; infufa per dotur

\section{xxers}

Figure 1. Page 94 of Octavianus Mirandula's anthology Illustrium poetarum flores, containing quotations of Virgil's Georgics 4 and Aeneid 6. Image from the Excerpta Project. 


\section{Bibliography}

Arrizabalaga, J. (2009). Medical Ideas in the Sephardic Diaspora: Rodrigo de Castro's Portrait of the Perfect Physician in Early Seventeenth-Century Hamburg. In T. Huguet-Termes, J. Arrizabalaga, \& H. J. Cook (Eds.), Health and Medicine in Hapsburg Spain: Agents, Practices, Representations (Medical History, Suppl. 29; pp. 107-124). London: Wellcome Trust.

Cardoso, A. (2012). A Biblioteca proposta por Rodrigo de Castro em 'O Médico Político'. Ágora: Estudos Clássicos em Debate, 14(1), 159-167.

Castro, R. de (1603). De uniuersa mulierum medicina, novo et antehac a nemine tentato ordine opus absolutissimum. Hamburg: in officina Frobeniana, excudebatur typis Philippi de Ohr.

Castro, R. de (1614). Medicus-politicus. Siue de officiis medico-politicis tractatus. Hamburg: ex Bibliopolio Frobeniano.

Castro Jiménez, M. D. (2006). Horacio en los florilegios medievales. In A. A. Nascimento, \& P. F. Alberto (Eds.), Actas do IV Congresso Internacional de Latim Medieval Hispânico (pp. 293-303). Lisboa: Centro de Estudos Clássicos.

Conde Parrado, P. (2001). La poesía clásica en los médicos españoles del Renacimiento. In J. L. García Hourcade, \& J. M. Moreno Yuste (Eds.), Andrés Laguna. Humanismo, ciencia y política en la Europa renacentista (pp. 259-270). Valladolid: Junta de Castilla y León, Consejería de Educación y Cultura.

Curbelo Tavío, M. H., \& Paso Carrasco, M. D. G. (2020a). La selección de los extractos virgilianos de la Eneida en los florilegios del siglo XVI. In G. R. Herrera (Ed.), Florilegios latinos y sociedad (pp. 29-67). Vigo: Editorial Academia del Hispanismo.

Curbelo Tavío, M. H., \& Paso Carrasco, M. D. G. (2020b). Extractos atribuidos a Virgilio y el canto XIII de La Eneida en los florilegios latinos del siglo XVI. Graeco-Latina Brunensia, 25(2), 47-60.

Domingues, A. J. (2002). Os clássicos latinos nas antologias escolares dos Jesuitas nos primeiros ciclos de estudos pós-elementares no século XVI em Portugal. Porto: Faculdade de Letras da Universidade do Porto.

Excerpta Project $=$ Proyecto Excerpta. Instituto Universitario de Análisis y Aplicaciones Textuales, Universidad de Las Palmas de Gran Canaria (ed. G. R. Herrera). [http://excerpta.iatext.ulpgc. es; accessed 21.03.2021].

Fairclough, H. R. (1999). Virgil. Eclogues, Georgics, Aeneid: Books 1-6 (rev. G. P. Goold). Cambridge, MA: Harvard University Press.

Förg, M. (2020). Die bedrohte Stadt. Rodrigo de Castro und die Hamburger Pestepidemie von 1596/97. In M. Gadebusch Bondio, Ch. Kaiser, \& M. Förg (Eds.), Menschennatur in Zeiten des Umbruchs. Das Ideal des politischen Arztes in der Frühen Neuzeit (pp. 47-82). Berlin - Boston: De Gruyter.

Frade, F. V., \& Silva, S. N. (2011). Medicina e política em dois físicos judeus portugueses de Hamburgo: Rodrigo de Castro e o Medicus Politicus (1614), e Manuel Bocarro Rosales e o Status Astrologicus (1644). Sefarad, 71, 51-94.

Gemma, C. (1575). De naturae diuinis characterismis, seu raris et admirandis spectaculis, causis, indiciis, proprietatibus rerum in partibus singulis uniuersi, libri II. Antwerp: ex officina Christophori Plantini.

Horsfall, N. (2013). Virgil, Aeneid 6: A Commentary (2 Vols.). Berlin: De Gruyter. 
Kayserling, M. (1901-1906). Rodrigo de Castro. In I. Singer (Ed.), The Jewish Encyclopedia (12 Vols.). New York - London: Funk-Wagnalls.

McGill, S. (2005). Virgil Recomposed: The Mythological and Secular Centos in Antiquity. Oxford: Oxford University Press.

Miranda, M. (2001). Humanismo jesuítico e identidade da Europa. Uma 'Comunidade pedagógica europeia'. Humanitas, 53, 83-111.

Mirandula, O. (1538). Illustrium poetarum flores, per Octauianum Mirandulam collecti et a studioso quodam summa diligentia in locos communes digesti. Strasbourg: ex aedibus Wendelini Rihelii.

Moss, A. (1996). Printed Commonplace-Books and the Structuring of Renaissance Thought. Oxford: Clarendon Press.

Mota, B., Pinheiro, C. S., \& Silva, G. A. F. (forthcoming). Rodrigo de Castro. A peste de Hamburgo: Tratado breve da sua natureza e causas. Introdução, tradução e notas (Prólogo por J. Arrizabalaga). Porto: Afrontamento.

Mynors, R. A. B. (Ed.). (1990). Virgil: Georgics. Oxford: Clarendon Press.

Pinheiro, C. S. (2017). The Ancient Medical Sources in the Chapters about Sterility of Rodrigo de Castro's De uniuersa mulierum medicina. In G. Davies, \& T. Loughran (Eds.), The Palgrave Handbook of Infertility in History: Approaches, Contexts and Perspectives (pp. 291-310). London: Palgrave Macmillan.

Ratio atque Institutio Studiorum Societatis Iesu. Auctoritate Septimae Congregationis Generalis aucta (1635). Antwerp: Joan Meursium.

Salanitro, G. (1997). Osidio Geta e la poesia centonaria. Aufstieg und Niedergang der römischen Welt, II, 34(3), 2314-2360.

Schmeling, G. (2011). A Commentary on the Satyrica of Petronius. Oxford - New York: Clarendon Press.

Steucus, A. (1540). De perenni philosophia libri X. Lyon: excudebat Sebastian Gryphius.

Toipa, M. H. R. A. C. (2017). De ratione liberorum instituendorum litteris Graecis et Latinis de Pedro Perpinhão: na génese da Ratio Studiorum da Companhia de Jesus. In N. N. C. Soares, \& C. Teixeira (Eds.), Legado clássico no Renascimento e sua receção: contributos para a renovação do espaço cultural europeu (pp. 353-373). Coimbra: Imprensa da Universidade de Coimbra.

Veiga, R. de (1586). Opera omnia quae ad hunc usque diem in lucem prodierunt. Lyon: apud Ioannem Lertout.

Wilson-Okamura, D. (2010). Virgil in the Renaissance. Cambridge: Cambridge University Press.

Gabriel A. F. Silva, PhD / gabriels@campus.ul.pt

Centre for Classical Studies

University of Lisbon, School of Arts and Humanities

Alameda da Universidade, 1600-214 Lisboa, Portugal

This work can be used in accordance with the Creative Commons BY-SA 4.0 International license terms and conditions (https://creativecommons.org/licenses/by-sa/4.0/legalcode). This does not apply to works or elements (such as image or photographs) that are used in the work under a contractual license or exception or limitation to relevant rights 